\title{
Perception of topical ocular drug delivery: comparison between eyedrop instillation in open eyes and vaporisation in closed eyes
}

\author{
Percepção da aplicação tópica ocular de drogas: comparação entre \\ instilação de gotas em olhos abertos e vaporização em olhos fechados
}

Arlindo José Freire Portes ${ }^{1}$, Bruna Dantas Dias da Silva ${ }^{1}$, Laura Beliene Ramos Vieira1 ${ }^{1}$ Fernando Moreira dos Santos ${ }^{1}$, Nathalya Coutinho Gonçalves de Moraes ${ }^{1}$

\begin{abstract}
Objective: Evaluate how difficult it is to apply ocular topical medications based on patient observation and answers to a questionnaire. Eye drops in open eyes were compared to vaporization in closed eyes. Methods: The study was a randomized clinical trial paired and held in the months of august and september of 2012 in the ophthalmological department of Polyclinic Ronaldo Gazolla (Arcos da Lapa Campus, Faculty of Medicine, University Estáciode Sá, RJ) in 50 patients. The Optive ${ }^{\circledast}$ ophthalmic solution was applied topically via an eyedrop bottle or a vaporizer through a randomized process. Patients were asked pre-formulated questions about the practicality of both methods and the technique of topical ocular drug delivery was observed. Results: $32 \%$ informed that it was difficult or very difficult to vaporize and $34 \%$ to use eye drops $(p=0,9562)$. The major problem described by patients was to direct the eye drop to the eye surface. This difficulty was considered by $53 \%$ for vaporization and by $65 \%$ for topical eye drop use. $38 \%$ of the patients needed more than one eye drop application to have eye drop contact, while $30 \%$ of the patients needed more than one application of vaporization in order to get drug eye contact $(p=0,5224)$. In $74 \%$ of patients there were an eyedropper tip contact with cilia, however there was one eye finger contact when the medicine was vaporized $(p=0,5433)$. Conclusion: The ease perceived by patients to instil eye drops in open eyes was equivalent compared to the vaporization in closed eyes; the method of spraying was performed more appropriately due to the high frequency of eyedrop tip touches on the ocular surface.
\end{abstract}

Keywords: Volatilization; Administration topical; Ophthalmic solutions; Lubricants; Eye/drug effects

\section{RESUMO}

Objetivo: Avaliar por questionário qual o nível de facilidade ou dificuldade para aplicação tópica de medicações oculares: vaporização em olho fechado ou instilação de gotas em olho aberto e constatar por meio da observação de pacientes pelos autores qual o método que foi utilizado com maior adequação técnica para aplicação de drogas tópicas oculares. Métodos: A pesquisa foi um ensaio clínico pareado e randomizado, realizada nos meses de agosto e setembro de 2012 no ambulatório de Oftalmologia da Policlínica Ronaldo Gazolla (Campus Arcos da Lapa, Faculdade de Medicina da Universidade Estácio de Sá, RJ) em 50 pacientes conveniados de planos de saúde ou do SUS. Foi utilizado um frasco de colírio e um de vaporizador com solução Optive ${ }^{\circledR}$. Cada participante aplicou em um dos olhos a solução por vaporização ou instilação de gotas através de um processo randomizado. Foi perguntado aos pacientes questões pré-formuladas sobre a praticidade de ambos os métodos e observada à técnica de aplicação. Resultados: $32 \%$ acharam difícil ou muito difícil a vaporização em olho fechado e $34 \%$ a instilação de colírio ( $\mathrm{p}=0,9562)$. A dificuldade mais comum para ambos os métodos foi "acertar o olho" e ocorreu em $53 \%$ dos pacientes que tiveram dificuldades para vaporização e por $65 \%$ dos que apresentaram dificuldade para aplicação de colírio. $38 \%$ dos pacientes necessitaram de mais de uma instilação para aplicação do colírio, enquanto $30 \%$ dos pacientes precisaram de mais de uma aplicação para que a droga vaporizada tivesse contato com o olho ( $\mathrm{p}=0,5224)$. Em $74 \%$ dos pacientes houve toque da ponta do colírio com os cílios, já com o vaporizador não houve um toque do orifício do vaporizador com o dedo do paciente $(\mathrm{p}=0,5433)$. Conclusão: A maior facilidade ou dificuldade percebida pelos pacientes foi equivalente para instilar o colírio em relação à vaporização em olho fechado. O método da vaporização foi realizado mais adequadamente devido à frequência elevada de toques da ponta do colírio nos tecidos oculares.

Descritores: Volatilização;Administração tópica; Soluções oftálmicas; Lubrificantes; Olho/efeitos de drogas

\footnotetext{
${ }^{1}$ Universidade Estácio de Sá, Rio de Janeiro, RJ, Brasil.

Curso de Medicina, Universidade Estácio de Sá - Trabalho de IC de Oftalmologia
}

The authors declare no conflict of interest.

Received for publication 17/12/2012 - Accepted for publication 10/12/2013 


\section{INTRODUCTION}

$\mathbf{T}$ lopical eye drops remain the cornerstone of treatment of many eye diseases, including glaucoma and dry eye syndrome ${ }^{(1)}$.

Correct use of eye drops requires fine motor movements and adequate vision. Many patients, especially the elderly, have difficulty applying topical eye medications due to impaired motor coordination or impaired near vision without glasses ${ }^{(2)}$.

Recent studies have shown that most patients apply eye drops incorrectly, touching their eye tissues with the tip of the bottle, which can cause contamination ${ }^{(3,4)}$. Improper use of eye drops can also lead to higher systemic drug absorption with increased toxicity ${ }^{(5)}$.

Topical administration into the closed eye from a distance using the vaporisation method can be an alternative to traditional eye drop instillation in cases of physical incapacity due to preexisting diseases or when patients do not cooperate ${ }^{(6)}$. Furthermore, patients with eyelid inflammation, eyelid haematoma, or facial cellulitis can feel pain during topical application when the eyelid is touched. Administration can also be affected by a reduced eyelid opening in such diseases or in facial dystonia. However, children, adults or elderly patients who have normal vision but feel very anxious or nervous when they sense that an instilled drop will come into contact with their ocular surface will probably benefit the most from the vaporisation method. These patients often move their head or blink excessively when an eye drop bottle approaches their face. This behaviour prevents the drop from reaching the proper site in the tear film and may also induce contact between the bottle and ocular tissues ${ }^{(7)}$.

Eye drops often produce unpleasant sensations such as burning, stinging and tearing. Because of this, eye drop therapy can be difficult to administer to children due to their lack of cooperation, which is exacerbated by the need to keep their eyes open for the drops to be applied.

Some of the most important reasons for non-adherence to proper treatment with eye drops may be related to incorrect administration, which raises the cost of therapy ${ }^{(8)}$.

Drug administration through vaporisation in a closed eye can facilitate treatment in patients with high refractive errors, eye trauma, advanced age, postoperative patients, etc. as the method does not require the patient to see the tip of the bottle and bring it near their eye lashes, and it also requires less coordination.

Recent studies have shown that the efficacy of topical administration through vaporisation in closed eyes is equivalent to drop instillation in open eyes. The process is effective because the pressurised spray droplets reach the eyelid margin and remain in that area. When the patient opens his/her eyes, the droplets mix with the tear film ${ }^{(0,10,11)}$. There are commercial preparations available in other countries for vaporisation of ocular lubricants in closed eyes, such as Actimist Eye Spray, Dry Eyes Eye Mist, and Tears Again Advanced ${ }^{(11-14)}$. In Brazil ocular vaporisers are not commercially available.

After an extensive literature review in databases such as MEDLINE, Scielo and LILACS, no publications were found comparing topical the administration of eye medications through vaporisation in closed eyes versus eye drop instillation in open eyes.

\section{ОвJeCtives}

a) Apply a questionnaire to assess the level of difficulty experienced by patients while applying topical eye medications using vaporisation in closed eyes versus eye drops in open eyes.

b) Observe patients as they apply topical eye medications to determine which of the two methods was used with the more appropriate technique.

\section{Methods}

The study was a paired randomised clinical trial held between August and September 2012 at Polyclinic Ronaldo Gazolla (Arcos da Lapa Campus, Medical School, Estácio de Sá University, Rio de Janeiro) on 50 patients covered by the Brazilian public health system or by private insurance. Only patients who said they knew how to instil eye drops were included.

A pseudo-random Excel spreadsheet was generated to randomly assign the right or left eye for each type of topical drug administration.

Each participant was given a bottle of lubricant eye drops $\left(\right.$ Optive $\left.^{\mathrm{TM}}\right)$ and was asked to instil them in an open eye. After observing a demonstration by one of the researchers on how to use the vaporiser in a closed eye, each participant vaporised the Optive ${ }^{\mathrm{TM}}$ solution in the other eye. The vaporiser had a plastic spray pump coupled to a $7 \mathrm{ml}$ flask. The device is operated manually similar to a perfume spray, therefore the suction pressure on the bottle varies according to the manual pressure exerted at the nozzle. The Optive ${ }^{\mathrm{TM}}$ ophthalmic solution was introduced into the vaporiser and sterilised with ethylene oxide.

The method for vaporisation in a closed eye was as follows: the patient held the vaporiser approximately $3 \mathrm{~cm}$ from his/her eye, looking directly at the orifice from where the product would be released. Next, the patient closed the eye and activated the vaporiser. Administration was considered adequate when the fluid predominantly reached the margin of the closed lid, where the eyelashes are.

The process was observed by the authors. A questionnaire was administered after the procedure asking patients how practical they thought the methods were. Aspects related to the administration were also observed and classified by the authors.

The questionnaire and the items observed and classified by the authors are shown below:

\section{Results}

In total, 100 eyes of 50 patients were included in the study. Mean patient age was 61.7 years, with a standard deviation of 17.71 years. Of the 50 patients, $18(36 \%)$ were male and 32 $(64 \%)$ were female.

The number of subjects with difficulties instilling eye drops or using the vaporiser was similar: 17 (34\%) subjects had difficulties instilling eye drops and 16 (32\%) had difficulties using the vaporiser.

Most subjects (35) found it easy or very easy to instil eye drops. Similarly, most subjects (34) found it easy or very easy to use the vaporiser. There was no statistically-significant difference between the two methods ( $\mathrm{p}=0.9562$, Figure 1 ). 


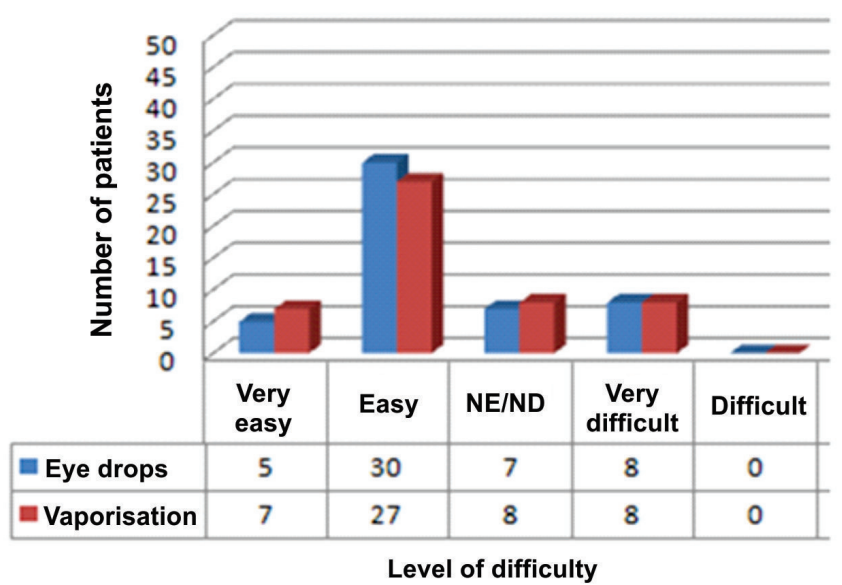

Figure 1: Difficulty instilling eye drops in an open eye versus vaporisation in a closed eye $(p=0.9562)$. NE/ND: Neither easy nor difficult.

The most common difficulty $(65 \%)$ reported by patients while instilling eye drops was "targeting the eye". The other difficulties are shown in Figure 2.
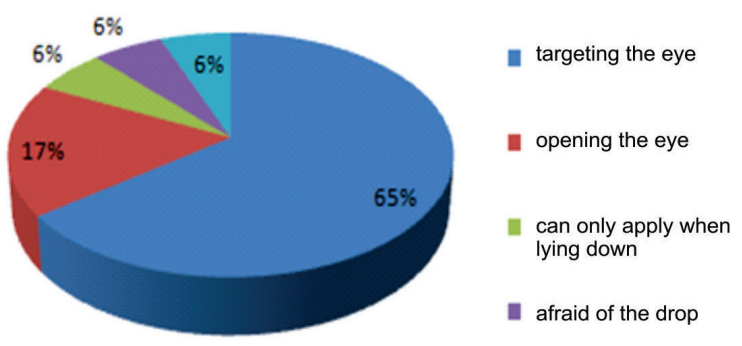

not used to the method

Figure 2: Difficulties reported by subjects while instilling eye drops.

The most common difficulty reported by patients while using the vaporiser was "targeting the eye". The other difficulties are shown in Figure 3.

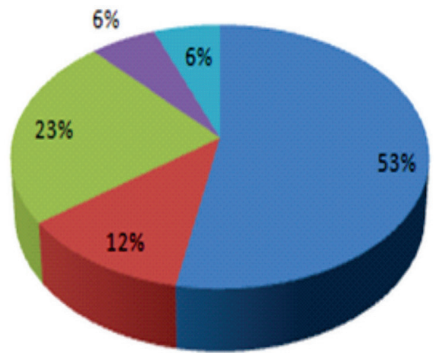

- targeting the eye
- too spread out
not used to the method
- discomfort
- unsure about correct application

Figure 3: reported by subjects while using the vaporiser

There was also no clinically or statistically-significant difference between groups as regards the number of repetitions needed for topical administration: 19 patients needed to re-apply eye drops and 15 needed to re-apply the vaporisation. In addition, 31 subjects reached the ocular surface in their first attempt while using eye drops, and 35 reached the eyelid margin while using vaporisation $(\mathrm{p}=0.5224)$. However, a greater number of patients needed to repeat administration a large number of times (three) to reach the ocular surface while using eye drops $(10 \%)$ than to reach the eyelid margin while using vaporisation $(2 \%, \mathrm{p}=0.115)$.

As regards contact of the bottle with human tissues, the tip of the bottle touched the eyelids 37 times during eye drop instillation, while only one patient touched the tip of the vaporiser with their fingers. The result was clinically and statistically significant (Figure 4).

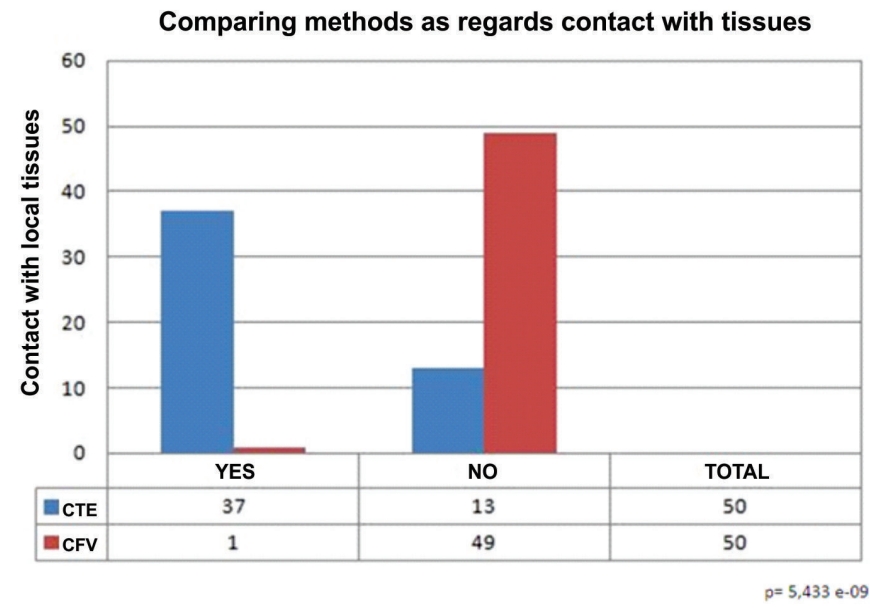

Figure 4: Comparing eye drop instillation in an open eye versus vaporisation in a closed eye as regards contact of the bottle with human tissues. CTE, contact between the tip of the bottle and the eye or eyelids; CFV, contact between the fingers and the vaporiser opening $(\mathrm{p}=0.000000005433)$.

\section{Discussion}

Vaidergon et al. ${ }^{(5)}$ found that patients with glaucoma had significant difficulties with the simple technique of instilling eye drops, which not only wasted the bottle contents, but also increased the chance of toxicity because patients needed to instil a greater number of drops. In the same study, there was no statistical correlation between the number of instilled drops and treatment time. The authors concluded that using the correct technique was critically important, because an improper technique could cause patients to instil a greater number of drops, leading to higher costs and hence poorer adherence to treatment. In the current work, we noticed that most patients had trouble targeting their eyes with eye drops $(65 \%)$ and touched their eyelids with the tip of the bottle to apply the medication $(74 \%)$, which can cause contamination of the bottle. Therefore, it is essential to teach patients the proper technique, even for those who have been using eye drops for many years and regardless of their educational and socioeconomic level.

In 2001 Höfling-Lima ${ }^{(15)}$ studied 127 eye drop bottles used by patients and found that $76.3 \%$ were contaminated after the bottle had been fully used due to contact of the tip of the bottle with ocular tissues. The most commonly-found microorganisms were species of the normal eye and skin flora. According to Vaidergon et al. ${ }^{(5)}$, contact between the tip of the bottle and ocular tissues produces suction of the tear film, which can alter the pharmacological properties of the product. Hence the importance of avoiding contamination not only to prevent infections and ulcers, but also to avoid changing the composition of the product in the bottle. Vaporisation of ocular lubricants is done at a distance, 
therefore the risk of contact with ocular or periocular tissues is minimal. In the present study only one patient touched the vaporiser opening with their finger during topical administration. There was a clinically and statistically-significant difference between the two techniques as regards contact with human tissues, suggesting that the vaporisation technique is safer.

In 2009, Portes et al. ${ }^{(16)}$ compared the difficulty of using the vaporisation method versus eye drops in open eyes and found that that $36 \%$ of subjects had difficulty vaporising their eyes compared with $14 \%$ of subjects using eye drops. Therefore, using the vaporiser in an open eye was more difficult than instilling eye drops. One explanation could be that subjects were not used to vaporisers or feared the contact of the vaporised ophthalmic solution with the ocular surface. However, in the present study we found that the level of difficulty was similar for vaporisation in a closed eye and eye drop instillation in an open eye. It is possible that patients were not afraid of using the spray with their eyes closed, increasing their confidence in the method. Perhaps the difficulty would be even lower if patients were already familiar with the method.

In our study, $10 \%$ of subjects needed to repeat eye drop instillation 3 times to reach the ocular surface, while only $2 \%$ needed to repeat vaporisation 3 times to reach the eyelid margin. Although this difference was not statistically significant with our sample of 50 patients, it could have been significant if the sample was larger. Vaporisation in closed eyes requires less fine motor skills than eye drop instillation in open eyes.

Considering that this is a new method for administration of eye medications, it is important to study how difficult the method is compared to eye drops, as it affects adherence to treatment.

Vaporisation of drugs in closed eyes is still being studied and should not be used for any medication commonly applied via eye drops, regardless of the agent in question, without prior scientific work confirming its effectiveness.

\section{Conclusion}

a) The level of difficulty was similar for the two methods of topical administration of eye medications.

b) The vaporisation technique was used more adequately, as it produced less contact of the tip of the bottle with the ocular surface.

\section{REFERENCES}

1. Stefan C, Cojocaru I, Pop A. [Glaucoma and ocular surface]. Oftalmologia.2011;55(1):30-3. Romanian.

2. Dietlein TS, Jordan JF, Lüke C, Schild A, Dinslage S, Krieglstein GK.Self-application of single-use eyedrop containers in an elderly population: comparisons with standard eyedrop bottle and with younger patients. Acta Ophthalmol. 2008;86(8):856-9.
3. Gupta R, Patil B, Shah BM, Bali SJ, Mishra SK, Dada T. Evaluating eye drop instillation technique in glaucoma patients. J Glaucoma. 2012;21(3):189-92.

4. Portes AJ, Silva MG, Viana M, Paredes AF, Rocha J. [Topical drug administration perception with and without eye drop applicator]. Rev Bras Oftalmol. 2011;70(4):224-9. Portuguese.

5. Vaidergorn PG, Malta RF, Borges AS, Menezes MDR, Trindade ES, Santiago JBN. [Eye drop instillation technique in chronic glaucoma patients]. Arq Bras Oftalmol. 2003; 66(6):865-9. Portuguese.

6. Bartlett JD, Wesson MD, Swiatocha J, Woolley T. Efficacy of a pediatric cycloplegic administered as a spray. J Am Optom Assoc. 1993;64(9):617-21.

7. Portes AJ, Barbosa AC, de Mello GL, Lopes MA, Cavalcanti RS. Tropicamide $1 \%$ mydriatic effect: comparison between spray in closed eyes and eye drops in open eyes. J Ocul Pharmacol Ther. 2012;28(6):632-5.

8. Stillitano IG, Lima MG, Ribeiro MP, Cabral J, Brandt CT. [Economic impact of eyedrop cost in glaucoma treatment]. Arq Bras Oftalmol. 2005;68(1):79-84. Portuguese.

9. Wong CY,Fan DS, Yu CB, Lam DS. Topical mydriatic and cycloplegic spray for Chinese children. J Pediatr Ophthalmol Strabismus. 2003;40(6):349-52.

10. Khaireddin R,Schmidt KG. [Comparative investigation of treatments for evaporative dry eye]. Klin Monbl Augenheilkd. 2010;227(2):12834. German.

11. Craig JP, Purslow C, Murphy PJ, Wolffsohn JS. Effect of a liposomal spray on the pre-ocular tear film. Cont Lens Anterior Eye. 2010;33(2):83-7.

12. Optrex ActiMist ${ }^{\mathrm{TM}}$ : product Information [Internet]. Slough (UK) Reckitt Benckiser Group; 2012 [cited 2012 Dec 16]. Available from: www.lloydspharmacy.com/en/optrex-actimist-2in1-dry-irritated-eyespray-10ml-13684.

13. Boots [Homepage internet]. Brand search results for Optrex [cited2012 Dec 06]. Available from: http://www.boots.com/en/Boots-Brands-A-toZ/Optrex/

14. Tears Again Spray ${ }^{\mathrm{TM}}$ : product Information [Internet]. Rosenberg,TX (USA); OCuSOFT; 2012 [cited 2012 Dec 16]. Available from: http:// www.tearsagainspray.com/

15. Höfling-Lima AL, Lima AS, Batistoso JA, Kawamura D, Chalita MR, Alves LS, et al. [Eyedroppe bottles contamination of autologous serum]. Arq Bras Oftalmol. 2001;64(1):63-5. Portuguese.

16. Portes AJ, Gomes LP,Amaral BL, Massa L. Percepção da administração tópica ocular de drogas: vaporização x gotas. Rev Bras Oftalmol. 2009;68(6):327-31.

\section{Corresponding author:}

Arlindo José Freire Portes.

Av. N. S. de Copacabana 195/409, Rio de Janeiro/RJ, Brazil

CEP: 22020-002

Telephone: +55212541 4398, Fax: +552125414532

E-mail: portes@uol.com.br 


\section{ANNEX 1}

Questionnaire and observed items on the perception of topical eye drug delivery: instillation of eye drops in an open eye versus vaporisation in a closed eye.

1. Chart number: :

2. Patient's initials:

3. Age:

\section{Questionnaire:}

4. How would you rate the instillation of eye drops?

1) Very easy ( ) 2) Easy ( ) 3) Neither easy nor difficult ( )

4) Difficult ( ) 5) Very difficult ( )

5. How would you rate the method of vaporisation in a closed eye?

1) Very easy ( ) 2) Easy ( ) 3) Neither easy nor difficult ( )

4) Difficult ( ) 5) Very difficult ( )

6. Do you have any difficulties with topical administration of eye drops? ( ) Sim （ ) Não. Se sim, qual(is)?

7. Em relação à vaporização em olho fechado, você possui alguma dificuldade? （） Sim （） Não. If yes, what are they?

\section{Observed itens:}

With regard to eye drops:

8. Did the instilled drop reach the eye? ( ) Yes ( ) No

9. Was it necessary to repeat instillation for the drop to reach the eye? $\quad(\quad$ ) Yes $(\quad)$ No

10. Did the tip of the bottle touch the eyelashes or eyelid?

( ) Yes ( ) No

11. How many drops were administered?

With regard to vaporisation in a closed eye:

12. Did the drug reach the eyelid margin? ( ) Yes ( ) No

13. Was it necessary to repeat the procedure? ( ) Yes ( ) No

14. Did the patient touch the vaporiser's tip with his/her fingers?

( ) Yes ( ) No

15. How many repetitions were needed?

The results were analysed with the R statistical software. Binomial data were examined using McNemar's paired test, and ordinal and discrete quantitative data were examined using Wilcoxon's paired test.

The level of significance for differences between groups was 0.05 .

Ethical aspects:

This study was submitted to and approved by the Research Ethics Committee of University Estácio de Sá. CAAE 0127.0308.000-11. 